\title{
NEM KONVENCIONÁLIS MEGOLDÁSOK NEUROBIOLÓGIAI JELEK NEM INVAZIV MÉRÉSTECHNIKÁJÁBAN
}

\section{NEW WAYS IN NON-INVASIVE NEUROBIOLOGICAL SIGNAL RECORDING}

\author{
Losonczi Lajos ${ }^{1,2}$ \\ ${ }^{I}$ Sapientia EMTE, Müszaki és Humántudományok Kar, Villamosmérnöki Tanszék, \\ Cím: Romania, Târgu-Mureș, Sighișoarei út, 1.C, Telefon: +40-722-352178, levele- \\ zési cím: lajos.losonczi@ms.sapientia.ro \\ ${ }^{2}$ Lambda Communications SRL,lajos@lambda.ro
}

\begin{abstract}
Due to the variable contact impedance, the existence of - movement, polarization and noise - artifacts at the contact level between the measuring electrode and the skin, the signal acquisition systems used in the brain computer interface (BCI) systems should meet very strict requirements during the measurement process of bioelectric signals. Because of the constantly changing measuring conditions of a system in motion and the noise disruptions, disturbances, interference that are greater than the measured signal, to achieve good results with an increased accuracy and a faster transmission and processing of the measured signals, specific and particular solutions are needed. In this paper I present those non-conventional solutions that result from the research I carried out in the last several years, and which can be successfully used in the non-invasive measurement of the neuro-biological signals.
\end{abstract}

Keywords: Instrumental amplifier, smart electrode, wireless embedded systems, BCI.

\section{Összefoglalás}

Az agy-számítógép interfész (BCI) rendszerekben alkalmazható jelbegyüjtő rendszerek a bioelektromos jelek mérése során nagyon szigorú követelményeknek kell eleget tegyenek egy mozgásban levő rendszer állandóan változó mérési feltételei miatt. A változó parméterek követése az érintkezési pontokban, a mérendő jelnél nagyságrendekkel nagyobb fellépő zajok, zavarok, interferenciák, a megnövelt mérési pontosság, a mért jelek gyors továbbítása és feldolgozása, mind olyan követelmények, melyek sajátos megoldások alkalmazását igényelik a jó eredmények elérése érdekében. A dolgozatban ismertetem azokat a nem konvencionális megoldásokat, amelyek az utóbbi évek személyes kutatási eredményeit foglalják össze és amelyek a nem invazív neurobiológiai jelek méréstechnikájában sikerrel alkalmazhatóak.

Kulcsszavak: mérö erősitők, okos elektródok, vezeték nélküli beágyazott rendszerek, mérörendszerek, $B C I$.

\section{Neurobiológiai jelek nem invaziv méréstechnikája}

Neurobiológiai eredetü elektromos jelek méréstechnikájában mindennapos dolog a $\mu \mathrm{V}$ nagyságrendü jelek mérése és feldolgozása. Az elektronikus alkatrészek folyamatos technológiai fejlődése lehetőséget nyújtott új generációs neurobiológiai mérö- és jelfeldolgozó rendszerek kifejlesztésére, ami új elrendezéseket eredményezett és jelentősen 
javított a berendezések paraméterein. Egy mai EEG mérőműszer fontosabb jellemzői: bemeneti jeltartomány $10 \mu \mathrm{V}-10 \mathrm{mV}$, sávszélesség $0,1 \mathrm{~Hz}-1 \mathrm{KHz}$, fázistorzítás 10 $20 \%$, mintavételezési felbontás 14-16 bit, zajelnyomás 80-100 dB. Az 1. ábra egy modern konvencionális neurobiológiai mérőrendszer tömbvázlatát szemlélteti [1].

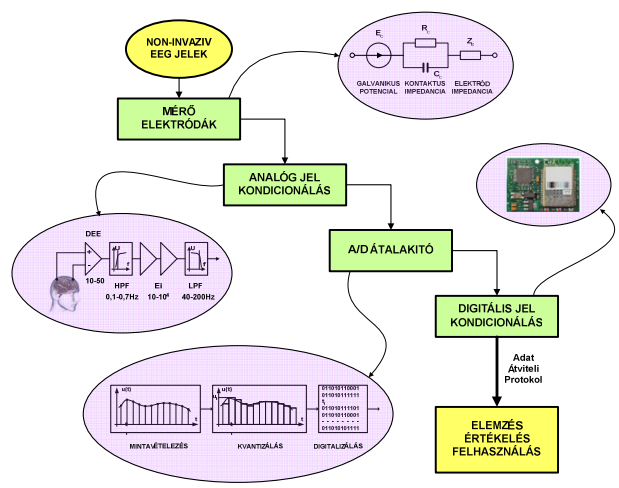

1. ábra. Neurobiologiai mérörendszer tömbvázlata

Az 1. ábra szerint az agy müködését kísérő elektromos potenciálváltozások mérése jól elhatárolható lépésekben történik. A modern klinikai diagnosztizáló mérörendszerekben nagy gondot fordítanak az elektródok illesztésére, az analóg és digitális jelkondicionálás minőségére, de főleg az analóg-digitális átalakítás pontosságára. A digitalizált jelek sokkal rugalmasabban kezelhetőek, mint az analóg technikában, ha az átalakítás nem marad el pontosságban az analóg erősítésben alkalmazott módszerektől. Egy adatsoron több feldolgozás is végezhető, miközben a mért adatok minősége már nem változik.

Ugyanakkor az analóg tartományból a digitálisra való áttérés néhány új szempontot és problémalehetőséget vezet be, amelyekre mindig tekintettel kell lenni [2]. Az adatátvitel tipusát, az alkalmazott kommunikációs protokol szerkezetét, a zajcsökkentő és zavarkompenzáló megoldások jó részét szintén a digitális technika határozza meg.

\subsection{BCI rendszerekben alkalmazható mérőrendszerek követelményei}

$\mathrm{Az}$ agy-számítógép interfész (BCI) rendszerekben alkalmazható jelbegyüjtő rendszerek esetében, ahol a fellépő zajok, zavarok, interferenciák amplitúdója a mérendő jelnél nagyságrendekkel nagyobb lehet, és állandóan változhat a mérések során, a bioelektromos jelek mérésének sokkal nehezebb követelményeknek kell eleget tennie [3]. Ezeknek a mérörendszereknek legalább még három funkcionális és technikai követelményt kell megoldaniuk:

- Viselhetőség: a felhasználó magán kell hordja a napi tevékenysége közben.

- Jellemző paraméterek további javítása: a kivonható információ növelése miatt.

- Valós idejủ jeltovábbítás és feldolgozás: a gyors válaszreakció érdekében.

Ezek a követelmények több funkcionális probléma megoldását is szükségeltetik:

- nagyon kis fizikai méretek;

- száraz elektródok használata;

- mozgási artefaktumok kompenzálása;

- kiterjesztett autonómia;

- tökéletesített rögzítési mechanizmus;

- drót nélküli kétirányú kommunikáció.

Ehez járul még a technikai problémák megoldása, ami azt eredményezi, hogy a fontosabb technikai paraméterek nem lehetnek gyengébbek, mint: a bemeneti jeltartomány $1 \mu \mathrm{V}-100 \mathrm{mV}$, sávszélesség $0,001 \mathrm{~Hz}-$ $40 \mathrm{KHz}$, fázistorzítás max. $1 \%$, mintavételezési felbontás 22-24 bit, zajelnyomás 100$120 \mathrm{~dB}$ [4].

\subsection{BCI-kompatibilis mérőstrukturák kialakítása és csoportosítása}

Kutatásaink során új méröstrukturák bevezetését kezdeményeztem. Az első lépés ma már általánosan alkalmazott módszer - 
az aktív elektródok használata [5]. A technológiai fejlödés lehetővé tette, hogy közvetlenül a mérőelektród fizikai kontaktusai mellé elhelyezhetők legyenek az analóg jelkondicionálás áramkörei: jelillesztők, mérőerősítők, szürők. Ez a megoldás nagyságrendekkel növelheti a jel/zaj viszony értékét [6].

A következő lépést a digitális jelkondicionálás egy részének - az analóg-digitális átalakítónak - a mérőelektródon való elhelyezése jelentette. Ez a megoldás lehetővé tette az adatok digitális továbbítását a méröpontból, csökkentve ezáltal a rendszer zavarérzékenységét. A 2. ábra egy aktív elektród tömbvázlatát szemlélteti, amit BCI céljára fejlesztettünk ki.

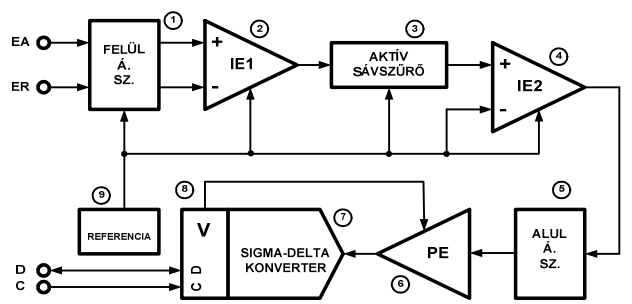

2. ábra. Aktív méröelektród

A jelfeldolgozás legalább egy részének a mérőelektródon való elhelyezése már egy újfajta elem, az intelligens mérőelektród (SAE - Smart Active Sensor, ez az általam adott elnevezés) megjelenését jelentette. A 3. ábra egy SAI tömbvázlatát szemlélteti.

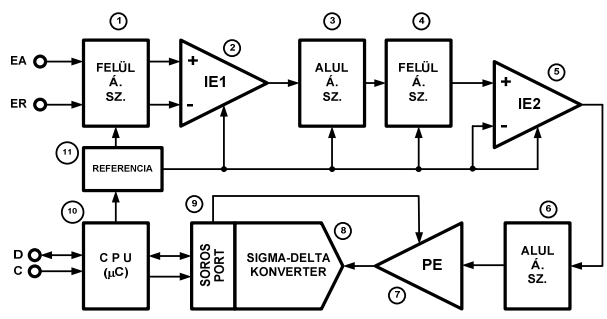

3. ábra. Intelligens méröelektród

Az okos mérőelektródok továbbfejlesztett változata már tartalmazza az analóg és digitális jelkondicionáló áramkörökön, il- letve a helyi vezérlést és jelfeldolgozást megvalósító mikrovezérlőn kívül a huzal nélküli kommunikációt megvalósító áramköröket és protokollokat is. Ez a struktúra a független mérőcsomópont (IRN - Independent Recording Node) elnevezést kapta. A 4. ábra egy független mérőcsomópont tömbvázlatát szemlélteti, amit BCIalkalmazásokra fejlesztettünk ki.

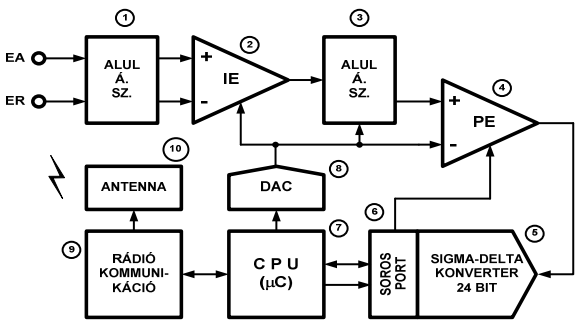

\section{4. ábra. Független mérőcsomópont}

Végül, a független mérőcsomópontokat elláttuk olyan áramkörökkel, amelyek az említett funkciók mellett még biztosítják az automatikus kalibrálást, az öntesztelést, a kontakt impedancia változásának valós idejü monitorozását, a zavarjelek kompenzálását, valamint a müködési mód programozott változtatását, illetve a technikai paraméterek (erősítés, sávszélesség, mintavételezési frekvencia, szürőkarakterisztika) vezérelt módosítását is. Ezeket a struktúrákat intelligens mérőmoduloknak (IRM - Intelligent Recording Module) neveztem el.

$\mathrm{Az}$ 5. ábra egy intelligens mérőmodul tömbvázlatát szemlélteti, amit BCIalkalmazásra fejlesztettünk ki.

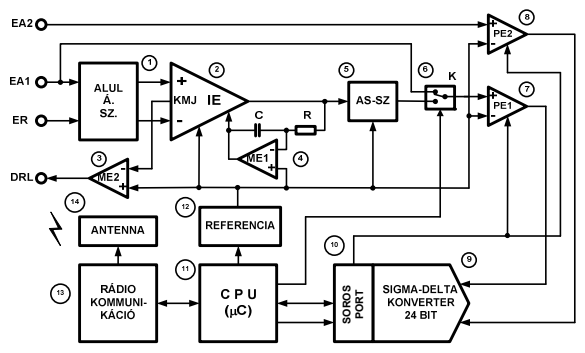

5. ábra. Intelligens mérömodul 


\subsection{Hálózatok BCI mérőstruktúrákkal}

A legtöbb esetben, a neurobiológiai jelek nem invazív mérése egyszerre több pontban történik. A legtöbb rendszer 21 elektródot használ, de gyakori a 40-60 pontos mérési technika alkalmazása, sőt komplex BCI alkalmazásoknál a mérési pontok száma elérheti a 120 pontot. Ebben az esetben a mérések szinkronizálása, az adatok kezelése és az információ továbbítása igen komoly feladatot jelent az adott biológiai környezetben. Ezt a feladatot nehezen lehet megoldani a klasszikus kommunikációs megoldásokkal, ahol a testen elhelyezett mérőelektródok dedikált, rendszerint huzalozott kapcsolatokon keresztül kommunikálnak a felsőbb szintekkel. Az általunk választott megoldást az intelligens beágyazott mérőáramkörök hálózatba kötése jelentette. Kétféle hálózatot fejlesztettünk ki, aszerint, hogy milyen mérőáramkört használtunk.

A 6. ábrán SAI-áramkörökkel képezett neurobiológiai mérőhálózat tömbvázlata látható.

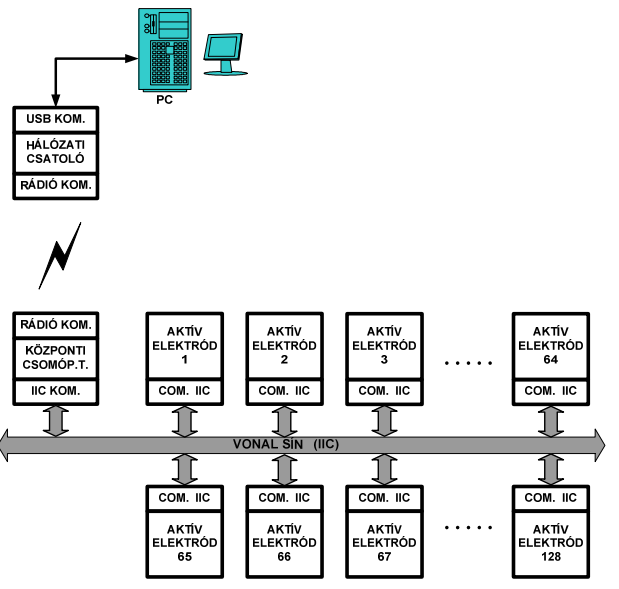

6. ábra. SAI-modulok hálózata

Az aktív elektródok egy klasztert képeznek a vonalsín körül, ezen keresztül kommunikálnak a központi csomóponttal, ami az átjáró (gateway) szerepét tölti be. A csomópont huzalozott kapcsolatban van a maximum 128 mérőelektróddal, és huzal nélküli kapcsolásban kommunikál a felsőbb szintekkel.

Jelenlegi kutatásaink tárgyát képezi a huzalozott vonalsín helyettesítése egy új, rövid hatótávolságú kapcsolódási technológiával (IBC - Intra-Body Communication), amely az emberi testet használja fel, hogy biztonságos kétirányú kommunikációt nyújtson két elektronikus készülék között. Összehasonlítva a meglévő vezeték nélküli módszerekkel az IBC jóval alacsonyabb energiafogyasztást kínál, miközben a kétirányú kódolt hitelesítés révén megnövelt biztonságot nyújt. Mivel a rendszer nem igényel RF antennát, így leegyszerüsíti az áramkör szintü tervezéseket, csökkenti az alkatrészek számát és a szükséges terület nagyságát.
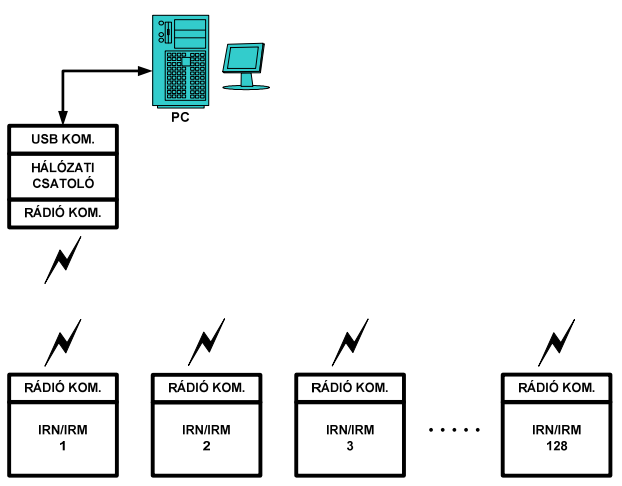

7. ábra. IRN-és IRM-modulok hálózata

A 7. ábrán IRN-, illetve IRMáramkörökkel létrehozott neurobiológiai mérőhálózat tömbvázlata látható.

Megfigyelhető, hogy az intelligens méröáramkörök hálózata ugyanazon a kommunikációs csatornán keresztül jön létre, amelyen ezek a felsőbb szintekkel is kommunikálnak. Az átjárót (gateway) kiküszöbölhettük a rendszerből, és a felsőbb szintnek lehetősége van arra, hogy közvetlenül megfigyelés alatt tartsa (monitoring) a mérőpontok közötti információcserét. 
Mindkét hálózati struktúra esetén a felsőbb kommunikációs szintet egy beágyazott hálózati csatoló jelenti, mely huzal nélküli csatornán kapcsolódik a hálózathoz és USB soros porton keresztül kapcsolódik a számítógéphez. Az általunk kifejlesztett hálózati csatoló tömbvázlata a $\mathbf{8}$. ábrán látható.

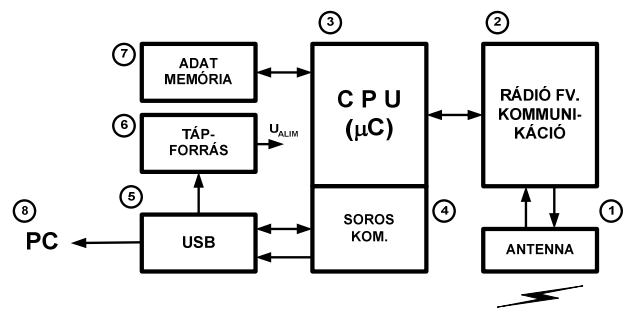

\section{8. ábra. Hálózati csatlakozó modul}

Az alkalmazott hálózati kommunikációs protokollt teljes egészében a kutatócsoportunk fejlesztette ki.

\section{Zajcsökkentő megoldások a BCI mérőstruktúrákban}

Az előző fejezetben ismertetett funkcionális és technikai követelményeket egyszerre kell teljesítenie egy BCI-kompatibilis mérőrendszernek. Ennek kellemetlen következménye, hogy az új áramköri megoldások bevezetésével együtt a zajok és zavarjelek hatása a rendszerre nagyságrendekkel megnő. Követelmény az új eljárások alkalmazása mind az analóg jelkondicionáló áramköri részen, mind a digitális jelkondicionálás vonalán, az említett hatások enyhítése érdekében.

\subsection{Zajcsökkentés az analóg jekondicionáló áramkörökben}

A zavarjelek hatásának csökkentését az analóg mérővonalon elsődlegesen a nagyon jó minőségü aranybevonatú elektródok használatával és csúcstechnológiájú integrált mérő (instrumentális) előerősítő áramkörök alkalmazásával értük el. Ezenkívül egy sor áramköri megoldásra volt szükség a BCI-kompatibilitás érdekében.

Már az egy nagy kihívás, hogy a viselhetőség érdekében szükséges a száraz elektródok használata. Ez azt jelenti, hogy a kontakt impedancia értéke $10 \mathrm{~K} \Omega$ nagyságrendről $1 \mathrm{M} \Omega$ nagyságrendre nő, a közös módú zavarjelek hatása 20-40 dB-értékkel nő, és legalább egy-két nagyságrenddel nő az elektródok polarizációs feszültsége, valamint az offset (nullponthiba) és a drift (nullpontvándorlás) feszültség a differenciális mérőerősítő bemenetén. Ahoz, hogy a fenti nehézségeket áthidaljuk, több nem konvencionális alkalmazást kellett bevezetnünk, melyek egyrészt nagymértékben csillapítják a zavarok káros hatását, másrészt a hasznos jelet nem vagy csak nagyon kis mértékben torzítják.

\subsubsection{A közös módú zaj elnyomása}

A száraz elektródok zavaró hatását a jelkondicionáló lánc elején kell kiküszöbölni. Az általunk speciálisan - zajos, kis amplitúdójú jelek illesztésére és erősítésére kifejlesztett mérő-erősítő elvi rajzát a 9. ábra szemlélteti. Megfigyelhető, hogy a rendszer két részből áll, egy bemeneti differenciális erősítő áramkörből (ME1-ME5 müveleti erősítők), valamint egy másodlagos transzkonduktív mérőerősítőből (TIE1, TIE2 transzkonduktancia müveleti erősítők és ME7, ME8 müveleti erősítők).

A tulajdonképpeni bemeneti diferenciális erősítőt az ME1 és ME2 erősítők alkotják, az ME3 és ME4 erősítők integrátorként vannak bekötve a negatív visszacsatolási hurokba, leválasztva ezáltal a mért jel egyenármú komponensét. Az ME5 erősítő a közös módú zavarfeszültséget vezeti vissza a negatív hurokba, jelentősen megnövelve a közös módú jelelnyomás, a CMRR értékét [7]. 


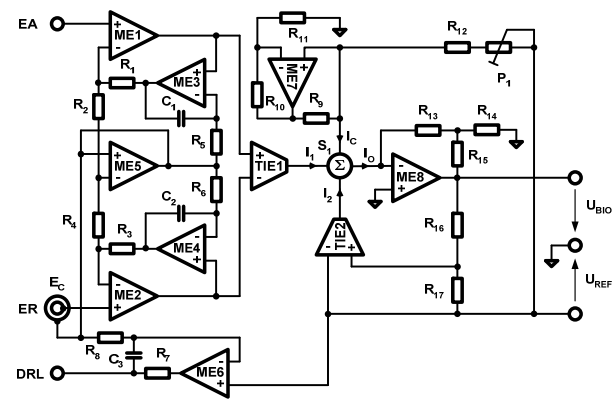

9. ábra. BCI kompatibilis méröerösitő

Az áramkörre, a szuperpozíció elvét alkalmazva, felírhatjuk:

$U_{o 1} \cdot\left(1+\frac{1}{s \cdot R_{6} \cdot C_{2}}\right)=\left(U_{o 1}^{\prime}+U_{o 1)}^{\prime \prime}\right) \cdot\left(1+\frac{1}{s \cdot R_{6} \cdot C_{2}}\right)=U_{t 1}\left(1+\frac{R_{3}}{R_{2}+R_{4}}\right)-U_{t a} \cdot \frac{R_{3}}{R_{2}+R_{4}}$

Hasonlóan:

$U_{o 2} \cdot\left(1+\frac{1}{s \cdot R_{5} \cdot C_{1}}\right)=\left(U_{o 2}^{\prime}+U_{o 2}^{*}\right) \cdot\left(1+\frac{1}{s \cdot R_{5} \cdot C_{1}}\right)=U_{i a}\left(1+\frac{R_{1}}{R_{2}+R_{4}}\right)-U_{i r} \cdot \frac{R_{1}}{R_{2}+R_{4}}$

A két egyenlet különbségét alkotva és alkalmazva a szimmetriakritériumokat: $R_{1}=R_{3}, R_{2}=R_{4}, C_{1}=C_{2}$ és $R_{5}=R_{6}$, kapjuk:

$$
\left(U_{o 2}-U_{o 1}\right) \cdot\left(1+\frac{1}{s \cdot R_{5} \cdot C_{2}}\right)=\left(U_{i a}-U_{i r}\right) \cdot\left(1+\frac{R_{1}}{R_{2}}\right)
$$

vagyis:

$U_{o 2}-U_{o 1}=\left(U_{i a}-U_{i r}\right) \cdot\left(1+\frac{R_{1}}{R_{2}}\right) \cdot \frac{s \cdot R_{5} \cdot C_{1}}{1+s \cdot R_{5} \cdot C_{1}}$

Másrészt, ha G1 a TIE1 transzkonduktancia erősítő erősítése, akkor:

$I_{1}=G_{1} \cdot\left(U_{o 2}-U_{o 1}\right)$

A TIE2 transzkonduktancia erősítő bemeneti feszültsége:

$$
U_{i t 2}=\left(U_{B I O}-U_{R E F}\right) \cdot \frac{R_{17}}{R_{16}+R_{17}}
$$

Hasonló módon felírhatjuk:

$$
I_{2}=-G_{2} \cdot\left(U_{B I O}-U_{R E F}\right) \cdot \frac{R_{16}}{R_{16}+R_{17}}
$$

Az ME8 müveleti erősítővel létrehozott transzimpedancia erösítő bemeneti árama zéró kell legyen, az ME8 és TIE2 erösítők hatalmas hurokerösítése miatt, ezért, ha nem vesszük figyelembe az ME7 kalibráló erősítő áramát, kapjuk, hogy: $I_{1}=-I_{2}$

Következik a (2) és (3) egyenletek alapján:

$$
U_{B I O}=\frac{G_{1}}{G_{2}} \cdot\left(1+\frac{R_{16}}{R_{17}}\right) \cdot\left(U_{o 2}-U_{o 1}\right)+U_{R E F}
$$

Behelyettesítve az (1) egyenlet értékét a (4) egyenletbe, megkapjuk a mérőerősítő frekvenciafüggő feszültségerősítését:

$U_{B I O}=\frac{G_{1}}{G_{2}} \cdot\left(1+\frac{R_{16}}{R_{17}}\right) \cdot\left(1+\frac{R_{1}}{R_{2}}\right) \cdot\left(\frac{s \cdot R_{5} \cdot C_{1}}{1+s \cdot R_{5} \cdot C_{1}}\right) \cdot\left(U_{i a}-U_{i r}\right)+U_{R E F}$

Következik, hogy az erősítő vágófrekvenciája (felüláteresztő szürőkarakterisztika):

$$
f_{t}=\frac{1}{2 \cdot \pi \cdot R_{5} \cdot C_{1}}
$$

Az egyenáramú komponens esetén $(s=0)$ :

$$
U_{B I O}=U_{R E F}
$$

A vágófrekvenciánál nagyobb frekvenciájú komponensek esetén:

$$
U_{B I O}=\frac{G_{1}}{G_{2}} \cdot\left(1+\frac{R_{16}}{R_{17}}\right) \cdot\left(1+\frac{R_{1}}{R_{2}}\right) \cdot\left(U_{i a}-U_{i r}\right)+U_{R E F}
$$

$\mathrm{Az}$ áramkör ofszet feszültségét a P1 potenciométerrel nullázhatjuk, úgy vezérelve az ME7 transzimpedancia érösítő kimeneti áramát, hogy a differenciális erősítő rövidre zárt bemenetei esetén $U_{B I O}=U_{R E F}$ egyenlöséget kapjuk.

\subsubsection{A kontaktimpedancia-változás kom- penzálása}

Viselhető száraz elektródok esetében a mozgásban levő felhasználón végzett méréseket jelentősen megnehezíti a kontaktimpedancia véletlenszerü változása. A mérés során szerzett információ minősége szorosan összefügg a mérőelektród és az érintett bőrfelület közötti kapacitív jellegü impedanciával, ezért szükséges az impedancia 
valós időben történő mérése, a hasznos jel korrekciója céljából. Fontos, hogy egyetlen elektród kontaktimpedanciáját mérjük meg, és a mérés ne két mérö-elektród között történjen, mivel ebben az esetben csak a két elektród impedanciaösszegét tudjuk megállapítani, és az impedanciaváltozás is nehezen lokalizálható pontosan.

A problémát úgy oldottuk meg, hogy egy sajátos elektródelrendezést használtunk, amint az a 10. ábrán látható.

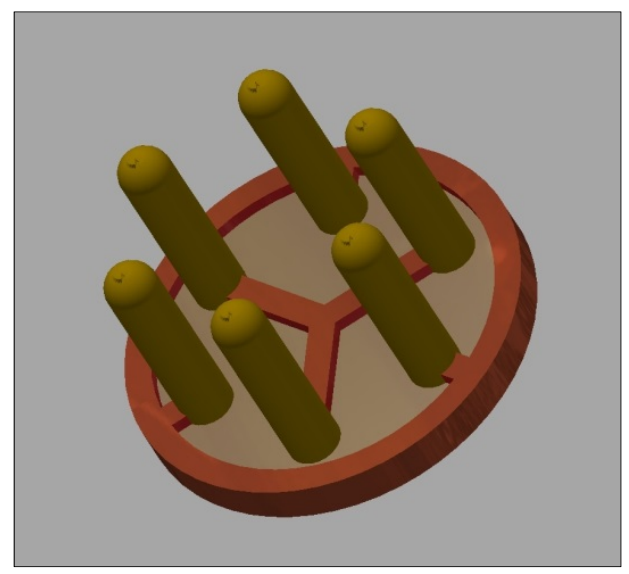

10. ábra. Méröelektród fej a hasznos jel és a kontaktimpedancia mérésére

A 6 darab kör mentén elhelyezkedö tüskeérintkező hármasával összekötve két különálló elektródot képez: a neurobiológiai jelet méróelektródot (ME) és a kontaktimpedancia méréséhez szükséges segédelektródot (SE).

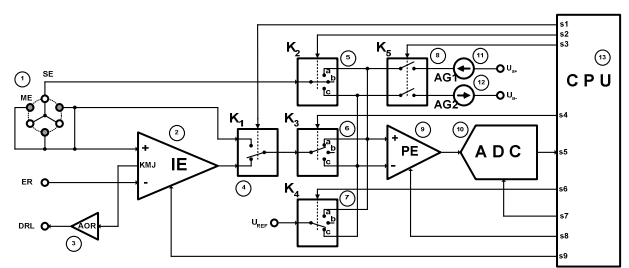

11. ábra. Méröelektród a hasznos jel és a kontaktimpedancia mérésére - hasznos jel mérése
A kontaktimpedancia mérése öt elektronikus kapcsoló segítségével történik, melyeket az intelligens mérőelektród beágyazott mikrovezérlője kapcsolgat egy kidolgozott protokoll szerint (11. ábra).

A rajzon látható, hogy a $\mathrm{ME}$ jele egy mérőerősítőn (IE) keresztül, míg a SE jele közvetlenül kerül a K1 kapcsoló bemeneteire. A 11. ábra jelölése szerinti kapcsolóállásnál a hasznos jel mérése történik. Ebben az esetben az analóg-digitális átalakítót megelőző programozható nyereségủ erősítő (PE) differenciális bemeneteire a mérendő jel, illetve a referenciafeszültség kerül. A 12. ábra jelölése szerinti kapcsolóállásnál, a kontaktimpedancia mérése történik. Ekkor a PE erősítő bemeneteire közvetlenül a mérő- (ME) és segéd- (SE) elektródok kötődnek. Ugyanakkor a két elektród közötti kontakt börfelületen átfolyik az ellensorba kötött AG1 és AG2 áramgenerátorok konstans árama: $I_{C}=10 \mu \mathrm{A}$. A PE erősítő által mért feszültség $U_{P E_{I}}=I_{C} \cdot R_{K I}$ arányos a méröelektród kontaktimpedanciájával.

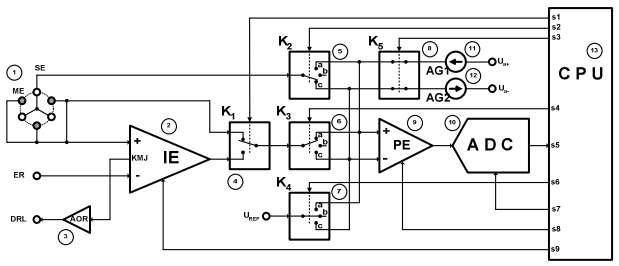

12. ábra. Méröelektród a hasznos jel és a kontaktimpedancia mérésére - kontakt impedancia mérése

Megfigyelhető, hogy a K2 és K3 kapcsolók ellentétes pozícióba való átkapcsolásával az ME és $\mathrm{SE}$ elektródokon áthaladó $\mathrm{I}_{\mathrm{C}}$ áram iránya megfordítható. Impedanciamérés közben ajánlott a méröáram irányának váltakoztatása, hogy elejét vegyük az elektródok polarizálásának elektrolízis útján. 


\subsubsection{A hálózati $(50 \mathrm{~Hz})$ zavarjel kompen- zálása}

A neurobiológiai mérőrendszerek legerőteljesebb zavarforrása a szinte mindenhol jelenlevő táphálózati szinuszos $(50 \mathrm{~Hz})$ feszültség, mely mint közös módú zavarjel tevődik rá a differenciális mérő-előerősítő bemeneteire. Bármilyen kis eltérés a bemenetek szimmetriájától a közös módú jelelnyomás (CMRR) nagymértékü csökkenéséhez vezet, az áram és feszültségdriftek hatására. Ezt a hatást csökkenteni lehet, ha korlátozzuk a bemenetek relatív potenciálváltozását - a közös módú jel hatására - az erősítő tápfeszültségéhez képest. Ez úgy érhető el, ha a közös módú jel rátevődik az előerösítő U+ és U- tápfeszültségeire. A 13. ábrán látható az alkalmazott megoldás elvi rajza. A mérőerősítő bemeneteire kapcsolódik - egy elektromágneses interferenciaszűrőn keresztül - a mérőelektród (ME), illetve a referenciaelektród (RE). A méröerősítő közös módú jelkimenete egy illesztő, feszültségkövető műveleti erősítoon keresztül kapcsolódik a két összegező műveleti erősítő ME1 és ME2 pozitív bemeneteire. E két utóbbi erősítő visszacsatolt negatív bemeneteire kapcsolódnak az áramkör szürt és stabilizált tápfeszültségei, két konstans $100 \mu \mathrm{A}$ áramú áramgenerátoron keresztül.

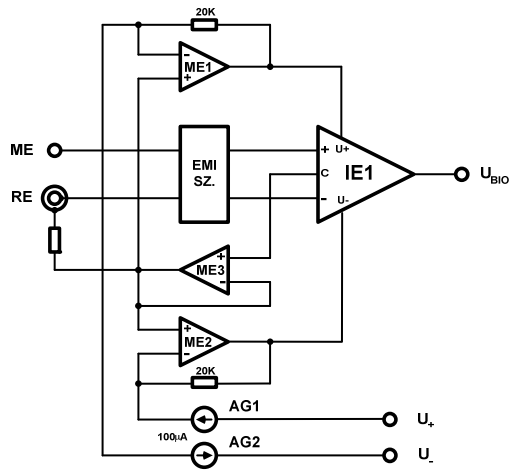

13. ábra. Közös módú jelelnyomás tápfeszültség-kompenzálással
A mérőerősítő tápfeszültségeire a következő összefüggéseket kapjuk:

$U_{A+}=U_{C M}+I_{G} \cdot R$

illetve:

$$
U_{A-}=U_{C M}-I_{G} \cdot R
$$

Az bemutatott eljárás alkalmazásával az általunk fejlesztett intelligens mérőmodulon a CMRR 10-20 dB nagyságrendü növekedését értük el.

\subsection{Zajkompenzálás a digitális jel- kondicionáló oldalon}

A digitális jelkondicionáló oldalon is hatásos eljárásokat dolgoztunk ki a zavarjelek elnyomására. Az első intézkedést e célból az analóg jelkondicionáló áramkörök drasztikus lecsökkentése jelentette, újszerü, rendkívül nagy felbontású analóg-digitális átalakító alkalmazásával. Az alkalmazott 4 . rendű Delta-Szigma modulátor és az azt követő 6. rendủ huzalozott digitális szürő, majd az ezt követö 2. rendủ szoftver FIR szürő, 24 bites - 21 bit effektív - felbontást biztosít, ami elegendő dinamikát jelent a bemenő jel fogadására ahhoz, hogy az analóg rész gyakorlatilag az illesztő előerősítőre redukálódjon [8]. Így jelentősen lecsökken a méröcsatorna érzékenysége a hőmérséklet-változásokra, az elektromágneses interferenciákra, az elektronikus alkatrészek aszimmetriáira és nem utolsósorban a technikai paraméterek szórásaira.

\subsubsection{A kontaktimpedancia és a fázistor- zítás kompenzálása}

A 14. ábra szemlélteti az alkalmazott megoldást. A mérő-előerősítő által leválasztott közös módú jel az ME müveleti illesztő erősítőn átvezetve negatív előjellel visszavezetödik a test felületére a DRL (drive right leg) elektródon keresztül. A DRL visszacsatoló hurkot kihasználva az ME erősítő bemenetéhez hozzáadjuk egy szinuszos, $10 \mathrm{Khz}$ frekvenciájú, $1 \mathrm{mV}$ amplitúdójú generátor jelét. Ez a - DRL elektródon kiküldött - jel rátevődik a ME mérőelektród 
hasznos jelére, és mérhető lesz az IE2 második mérőerösítővel. A mért jelet egy $10 \mathrm{KHz}$ központi frekvenciájú lyukszürőn áteresztve összehasonlítjuk az eredeti kibocsájtott jellel, egy szinkron demodulátor segítségével.

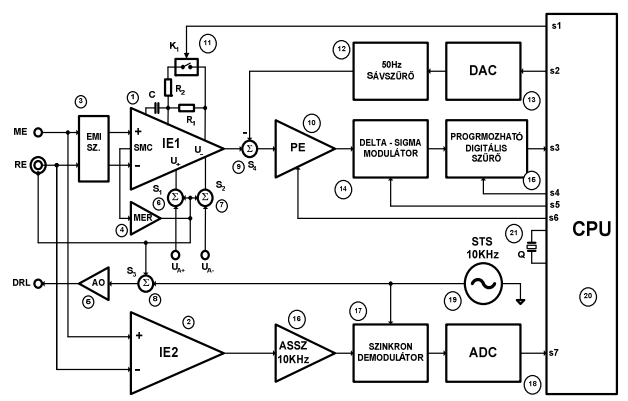

14. ábra. Intelligens mérömodul-zajkompenzálás a digitális oldalon

A mért fáziskülönbség arányos lesz a fázistorzítás nagyságával, az amplitúdóváltozást is figyelembe véve pedig a kontaktimpedancia változásáról kapunk információt. Az analóg szabályozó jeleket a digitális számításokban vesszük figyelembe, miután egy 16 bites átalakítóval digitális értékké alakítottuk őket.

\subsubsection{A hálózati zavarok kompenzálá- sa}

A 14. ábrán megfigyelhető, hogy az IE1 mérőerősítő kimenete és a Delta-Szigma modulátor bemenete közé egy összegező programozható nyereségü erősítőt iktattunk be. Ez lehetővé tette, hogy a mért hasznos jelhez - mely tartalmazza a hálózati $50 \mathrm{~Hz}-$ es zavarjeleket - hozzáadjunk egy numerikusan generált kompenzáló feszültséget. A kompenzáló jel egy 50 Hz-es direkt digitálisan szintetizált szinuszos jel, amelynek a fázisa és periódusa a detektált hálózati feszültég paramétereivel szinkronban van. A generált jel ellentétes előjelü a zavarjelhez képest, amplitúdója pedig numerikusan szabályozható a zavarjel nagysága függvé- nyében. A módszer alkalmazásával további 10-15 dB hálózati zavarjel elnyomást értünk el.

\section{Elért eredmények}

$\mathrm{Az}$ ismertetett megoldások használata lehetőséget nyújtott egy új struktúrájú intelligens mérőpontok beágyazott hálózatának a kifejlesztésére, amelyek huzal nélkül kommunikálnak egymással és egy koordináló központi vezérlőegységgel. Mindenik mérőpont rendelkezik saját tápforrással és elegendő intelligenciával ahhoz, hogy önálló müködésre legyen képes. A kifejlesztett mérőstrukturák paraméterei teljes mértékben megfelelnek a BCI-rendszerek követelményeinek.

A 15. ábrán egy megvalósított független mérőcsomópont képe látható.

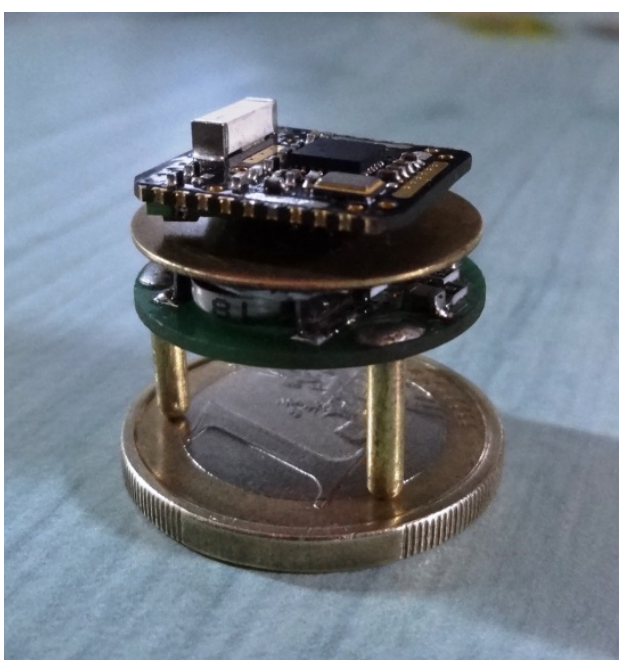

15. ábra. Független mérőcsomópont képe

Ez a struktúra három funkcionális modulból van kialakítva, együttesen egy minimális, $21 \mathrm{~mm}$ átméröjü, $14 \mathrm{~mm}$ magas henger alakú helyet foglalva el:

- analóg és digitális jelkondicionáló;

- vezérlő és rádió-kommunikáció;

- vezérelhető tápforrás. 
A jelkondicionáló modul sajátos elrendezésü mérőerősítőt és optimizált Delta-Szigma analóg-digitális, 24 bit felbontású konvertert tartalmaz és egyéb újszerü segédáramköröket, amelyek biztosítják az önkalibrálást, impedanciamérést, zajkompenzálást. A választott alkatrészeknek, valamint az alkalmazott eljárásoknak köszönhetően nagyon nagy közös módú bemeneti impedanciát $(>100 \mathrm{M} \Omega)$ és zajelnyomást (CMRR > $110 \mathrm{~dB})$ sikerült elérni és ugyanakkor szimmetrikus, kis torzitású $(<0,1 \%)$, nagy impedanciájú $(>100 \mathrm{M} \Omega)$ diferenciális bemeneti áramkört biztosítani.

A vezérlő és kommunikációs modul feladatait egy $2.4 \mathrm{GHz}$ adó-vevővel egybeépített 8051 alapú mikrokontroller látja el. A beágyazott rendszer szoftverét nagyrészt gépi kódban írtam, a gyorsaság, a tökéletes szinkronizálás és az optimális memóriahasználat érdekében. A $2 \mathrm{Mb} / \mathrm{s}$ feletti sebességü rádiófrekvenciás kommunikáció alkalmazása lehetővé teszi egyrészt a mérőpontok egymás közötti kommunikációját hálózati szinten, másrészt az adat- és parancskommunikációt szerverfelhasználó szinten. A jó helykihasználás érdekében kisméretü chip antennát használtunk.

Kifejlesztettünk egy kis energiaigényü, optimizált protokolt, ami az adatforgalom MAC rétegének az alapját képezi. Ráadásul a transzmisszió burszt (időszakos) módban történik, a fogyasztás csökkentése érdekében. A mérőelektród felsőbb kommunikációs szintje a hálózati csatlakozó modul, amely szintén saját fejlesztés.

A tápáramkörmodul is nehéz követelményeknek kell eleget tegyen. Mivel a minimalizálási feltételek miatt egyetlen standard 1,5 V-os gombelemet használunk feszültségforrásként, egy szinkron boost (növelö) konvertert integráltunk a rendszerbe, mely képes stabilan 2,7 V feszültséget szolgáltatni a kimenetén, az elem minimum 0,7 V-os kapocsfeszültségéig.

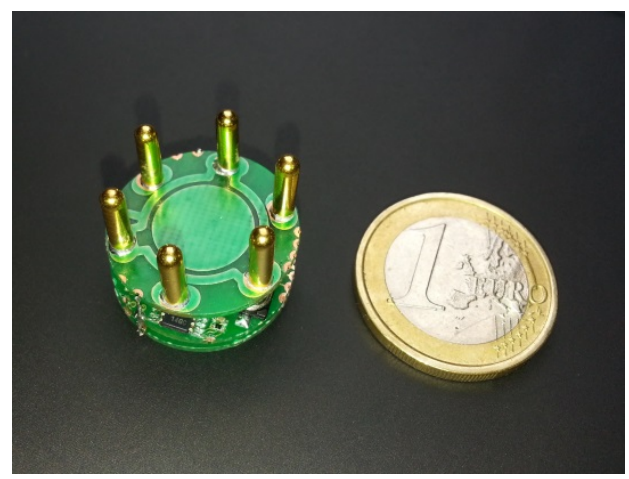

16. ábra. Kontaktimpedanciát monitorozó méröelektród képe

A 16. ábrán látható az elektródtüskék körkörös és megosztott elrendezése egy kontaktimpedanciát monitorozó mérőelektród esetén. Az áramkör átmérőjének mérete megegyezik egy 1 eurós pénzérme átmérőjével. A mérőelektród elvi rajzát a 17. ábra szemlélteti.

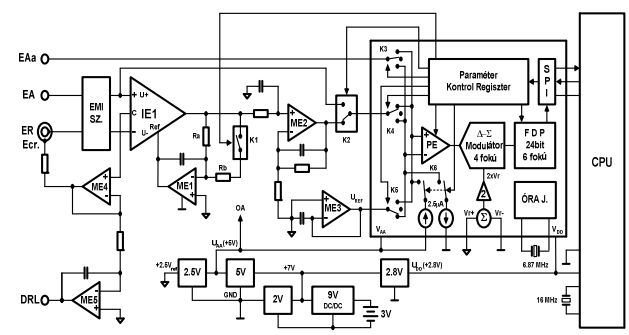

\section{7. ábra. Új típusú méröelektród elvi rajza}

A 18. ábrán egy megvalósított, új típusú mérőmodul képe látható. Méretei alig valamivel nagyobbak az előbb ismertetett mérőelektród méreteinél (22 mm átmérő, 15 mm magasság), de a megnövelt áramkörsürüségnek köszönhetően tartalmazza a 2 . fejezetben ismertetett összes zajcsökkentő és torzításcsökkentő alkalmazást. 


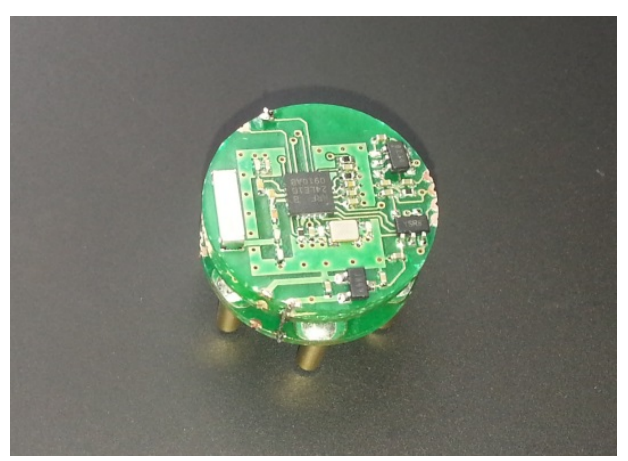

lyezkedik el, ezáltal mindenik elektród nagy felületen mozoghat. A 9. elektród a központi törzsön kapott helyet, és ez játszhatja a referenciaelektród szerepét. A modulok huzal nélkül kommunikálnak egymással és a felsőbb szintekkel, egyedül a törzsben elhelyezett tápforrás és a referenciapotenciál van huzalozva.

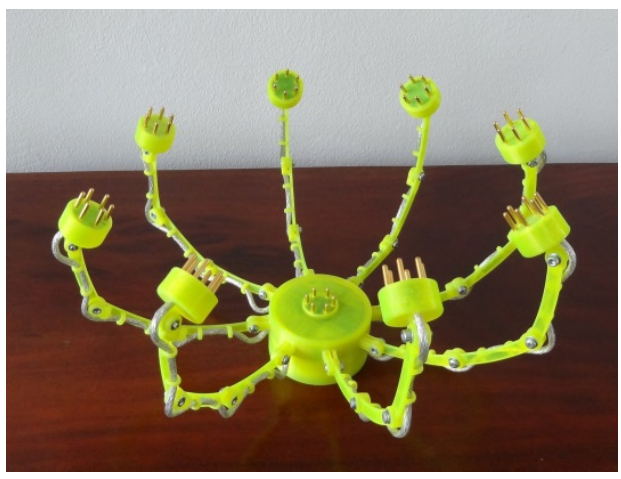

19. ábra. SAI modulok hálózata és rögzitö mechanizmusa

A rögzítő alkatrészeket 3D nyomtatóval nyomtattuk ki, PLA típusú műanyagból. modul háromtagú mozgatható karon he-

A mérőmodul elvi rajza a 20. ábrán van szemléltetve. Az áramkör paramétereit az 1. táblázat tartalmazza.

A BCI-rendszerekben alkalmazott mérőmodulok másik fontos követelménye a tökéletes rögzítési mechanizmus alkalmazása, a mozgási artefaktumok csökkentése miatt. A kifejlesztett mérőmodulok kis mérete és súlya lehetővé teszi a modulok könnyü rögzítését a fejtetőn.

A 19. ábra egy kísérleti rögzítési megoldásunkat szemlélteti. A nyolc mérő-

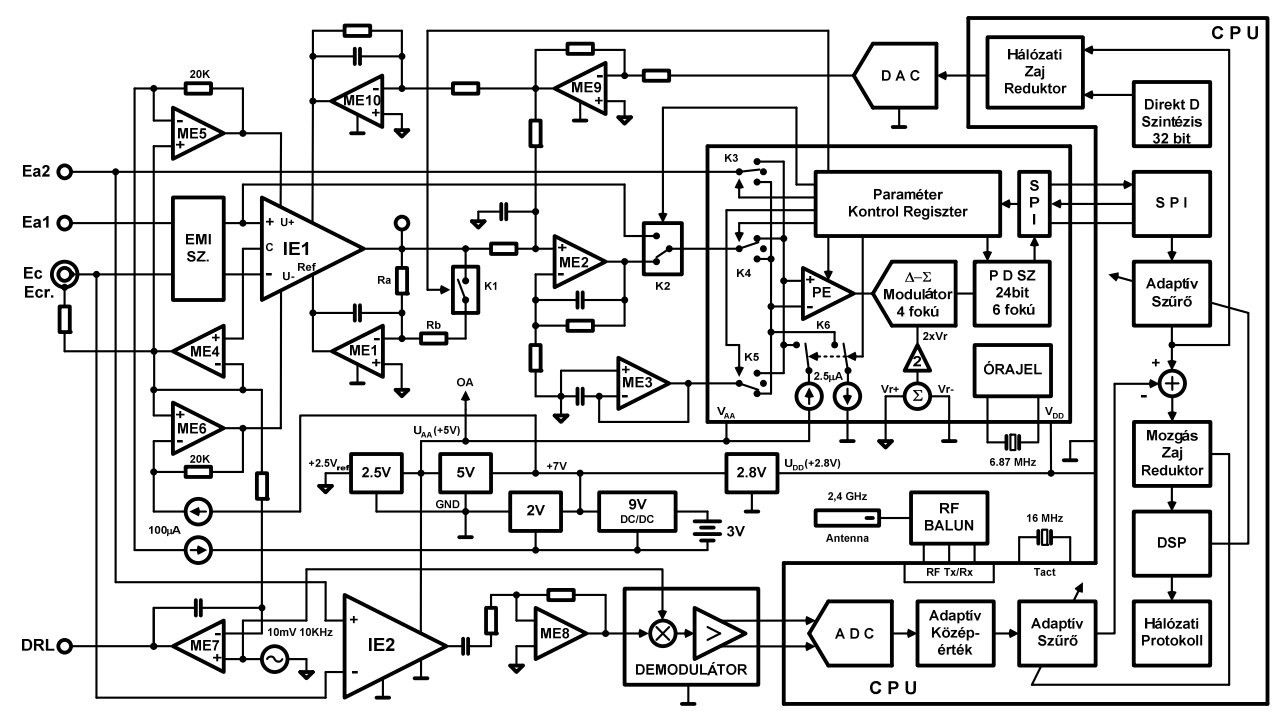

20. ábra. A megvalósitott intelligens mérömodul elvi rajza 


\section{Következtetések}

Kutatásunk célját a BCI kompatibilis mérő áramkörök kifejlesztése jelentette, egyrészt orvosbiológiai alkalmazásokra, hogy megnöveljük a páciensek életminőségét, egyben kényelmét és biztonságát, másrészt, hogy kiterjesszük a készülék alkalmazhatóságát más területekre is, mint: sport, multimédia, szórakoztatóipar, katonai alkalmazások, orvosi diagnosztizálás és biológiai kutatások.

$A z$ 1. táblázat tartalmazza az általunk eddig elért legjobb paraméterek közül a legfontosabbakat.

1. táblázat. A kifejlesztett neurobiológiai mérömodulok fontosabb paraméterei

\begin{tabular}{|c|c|c|}
\hline 1. & Bemeneti offset, max. & $2 \mathrm{mV}$ \\
\hline 2. & Drift feszültség, max. & $150 \mu V / C^{o}$ \\
\hline 3. & Saját zaj, $U_{\text {ZErel }}$ & $15 \% / 0,4 \mu \mathrm{V}$ \\
\hline 4. & Dif. impedancia & $10^{10} \Omega / 6 \mathrm{pF}$ \\
\hline 5. & Közös m. impedancia & $10^{11} \Omega / 8 \mathrm{pF}$ \\
\hline 6. & Torzító (bias) áram & $0,1 \mathrm{nA}$ \\
\hline 7. & Nem-linearitási hiba & $0,01 \%$ \\
\hline 8. & Relatív stabilitás, min. & $98 \%$ \\
\hline 9. & CMRR & $125 \mathrm{~dB}$ \\
\hline 10. & Analóg erősítés & $80 \mathrm{~dB}$ \\
\hline 11. & NEB (24b) & 21,3 \\
\hline 12. & Mérési doménium & $+/-2,2 \mathrm{~V}$ \\
\hline 13. & Kontakt impedancia & $80 \mathrm{~K} \Omega$ \\
\hline 14. & $\begin{array}{l}\text { Kontakt impedancia } \\
\text { mérési pontossága }\end{array}$ & $\begin{array}{l}\Delta R<3 \% \\
\Delta \varphi<1^{\circ}\end{array}$ \\
\hline 15. & Konverzióidő (24b) & $80 \mu \mathrm{S}$ \\
\hline 16. & Rezolució & $0,2 \mu \mathrm{V}$ \\
\hline 17. & Mintavételezés, max. & $40 \mathrm{kHz}$ \\
\hline 18. & Sávszélesség Hz, max. & $0,001-40 \mathrm{k}$ \\
\hline 19. & Fogyasztás, max. & $38 \mathrm{~mA}$ \\
\hline 20. & Átviteli sebesség & $2,1 \mathrm{Mb} / \mathrm{s}$ \\
\hline 21. & Adatátvitel, max. & $1,4 \mathrm{Mb} / \mathrm{s}$ \\
\hline 22. & Adatkésleltetés, max. & $400 \mu \mathrm{S}$ \\
\hline 23. & Átviteli távolság & $15 \mathrm{~m}$ \\
\hline 24. & Tápfeszültség & $1,5 \mathrm{~V} / 3,3 \mathrm{~V}$ \\
\hline 25. & Készenléti fogyasztás & $70 \mu \mathrm{A}$ \\
\hline 26. & Tápautonómia & $72 \mathrm{~h}$ \\
\hline
\end{tabular}

Az elért eredményekből megállapítható, hogy jó úton haladunk, a tervezett és létrehozott rendszer világszínvonalú paraméterekkel rendelkezik. A kutatást, fejlesztést tovább folytatjuk [9, 10, 11, 12].

\section{Szakirodalmi hivatkozások}

[1] Teplan, M.: Fundamentals of EEG measurement. Measurement Science Review, Slovak Academy of Sciences, Institute of Measurement Science, vol.2, sec.2, 2002.

[2] Baker, B.: Real Analog Solutions for Digital Designers. Elsevier, Oxford, UK, 2005.

[3] Yazicioglu, R. F., van Hoof, C., Puers, R.: Biopotential Readout Circuits for Portable Acquisition Systems. Springler, New York, 2009.

[4] Prutchi, D., Norris, M.: Design and Development of Medical Electronic Instrumentation. John Wiley, New Jersey, 2005.

[5] Neuman M.R.: Analysis and Application of Analog Electronic Circuits to Biomedical Instrumentation. CRC Press, London, 2004.

[6] Yoo, H. J., van Hoof, C.: Bio-Medical CMOS ICs. Springer, New York, 2011.

[7] Spinelli, E.M., és mások: A Novel Fully Differential Biopotential Amplifier with DC Suppression. IEEE Transactions on Biomedical Engineering, Vol.51, No.8, 2004.

[8] Schreier, R., Temes, G.C.: Understanding Delta-Sigma Data Converters. John Wiley, New Jersey, 2005.

[9] Losonczi, L.: Echipament pentru achiziția biosemnalelor $\mathrm{cu}$ rețea de noduri inteligente de măsurare. Cerere Brevet de Invenție, OSIM A201300623, 2013.

[10] Losonczi, L.: Metodă și echipament pentru măsurarea biosemnalelor. Cerere Brevet de Invenție, OSIM A201300610, 2013.

[11] Losonczi, L.: Procedeu și circuit pentru măsurarea impedanței de contact pieleelectrod. Cerere Brevet de Invenție, OSIM A201300611, 2013.

[12] Losonczi, L.: Modulator Delta-Sigma cu functia de transfer a zgomotului de cuantizare redus. Cerere Brevet de Invenție, OSIM A201300624, 2013. 